\title{
The Influence of Ubud Destination Quality on Brand Image, E-Wom and Revisit Intention
}

\author{
Ni Luh Nila Ratna Devi \\ Master of Management Study Program, Faculty of Economics and Business, Udayana University \\ Bali, Indonesia \\ Ni Nyoman Kerti Yasa \\ Master of Management Study Program, Faculty of Economics and Business, Udayana University \\ Bali, Indonesia
}

\begin{abstract}
Ubud Village is a well-known tourist destination in Bali, with its own distinct features and characteristics centered on culture and arts such as dance, painting, and architectural sculpture/carving, as well as its beautiful and natural natural beauty, making it a viable destination option. Tourism for cultural, spiritual, and recreational purposes. Because of the fierce competition among tourist destinations, Ubud must continue to compete and improve the quality of the destination, as well as the image/brand of the destination that is communicated through electronic media (e-WOM), which can influence the intention to visit and revisit intention to Ubud.The Servqual model was used to measure consumer perceptions of service quality at this location, which consists of five dimensions: tangible, empathy, reliability, responsiveness, and assurance. Then there's the impact on Ubud's image / brand image, as well as influence of e-WOM on revisit intention. Data was gathered from 156 domestic tourists who had visited Ubud in the previous three years. To establish the complexity of the relationship between latent variables and their indicators, the data were analyzed using Partial Least Square (PLS) statistics with the Smart PLS 3.0 computer tool.The results of this study indicate that each of the variables of Ubud destination quality, image/brand image, and e-WOM have a positive and significant effect on revisit intention. Then the quality of the Ubud destination also has a positive and significant effect on the image / brand image, and e-WOM. Other findings, image/brand image, and e-WOM are known to be able to mediate positively and significantly on the indirect effect of Ubud Destination quality on revisit intention.
\end{abstract}

Keywords: Destination quality, brand image, e-WOM, revisit intention, Ubud Destination

DOI: $10.7176 / \mathrm{EJBM} / 13-22-08$

Publication date: November $30^{\text {th }} 2021$

\section{Introduction}

Tourism has long been acknowledged as one of the most important factors in a region's development. Tourism success may assist enhance tourist acceptability in certain areas, increase regional income, and give job prospects in a certain location.

Bali is one of the provinces in Indonesia whose economy is based on tourism (BPS, 2019). Starting with the attractiveness of its natural attractions, the uniqueness of its culture, the friendliness of its population, and the diversity of relatively distinct culinary variants, Bali is a comprehensive package for a tourist vacation. There are also various types of tourist attractions on the island of Bali, ranging from beaches, terraced rice fields, forest and lake areas, volcanoes, waterfalls, and artificial tourist areas such as tourist villages that have been known to the world. The tourists that came to see the art did not miss it. Tourists are also drawn to the arts of dance, painting, gamelan music, and architectural art (Yustiani; 2019).

Every year, the number of tourists visiting Bali, both foreign and local, has increased. Up until the end of 2018, 6,070,473 foreign tourists were reported to have visited Bali directly, representing a 6.54 percent increase in total foreign tourist visits compared to 2017. Meanwhile, domestic tourists visiting Bali in 2018 totaled 9,757,991 visitors, up 11.70 percent from 2017. (www.bali.bps.go.id).

Ubud village in Gianyar district is one of the tourism locations in Bali that is still strong in retaining local wisdom as a spirit in the tourism sector. Ubud is well-known as a tourist destination with its own distinct personality and traits, emphasizing culture and the arts, such as dance, painting, and architectural sculpture. Furthermore, the Ubud area, with its natural beauty, is attractive and natural, making it a viable option for cultural, spiritual, and relaxation tourism (Sukawati: 2006).

By randomly selecting domestic tourist respondents, a preliminary survey was undertaken to evaluate public knowledge of Ubud as a tourist destination. The preliminary survey's results were distributed to 30 people. Table 1.1 shows that $100 \%$ of respondents had heard of Ubud destinations and have visited Ubud, and that $100 \%$ of respondents think that Ubud is a distinctive tourist destination focusing on culture and art. The results of this preliminary poll back up the preceding assertion about Ubud as a destination with its own distinct personality and traits. 
Due to increased international tourism operations, competition among tourist locations is very fierce. One method to survive and thrive in the tourism sector is to improve the service quality of these places. Quality locations are expected to entice new tourists to visit Ubud or to entice visitors who have already visited Ubud. Ubud has a positive image in the eyes of tourists due to the multiple achievements it has accomplished as a tourist destination. The quality of the Ubud destination and its image conveyed through electronic media (e-WOM) will be able to impact the intention to visit and the intention to return to Ubud if it is related with the rising use of information technology in marketing tourist destinations. This destination's quality measurement is based on the Servqual model (Parasuraman et al., 1988), which is a widely used model in service marketing research. Consumer impressions of service quality are measured using Servqual, which has five dimensions: tangible, empathy, reliability, responsiveness, and assurance. In the service industry, the most crucial element that clients can sense is service quality. Thus, each company maintains and improves the quality of its company services to build the company's image (Malik et al., 2011; Sawitri et al., 2013; Putra and Yasa, 2014; Adinegara et al., 2018). In addition (Gummesson and Gronroos, 1988) in (Malik et al., 2011) and Yulianti et al. (2014), reported that brand image is a key factor in the evaluation of overall service quality.

When it comes to determining the worth of a product, service quality is a critical factor (Imrie et al., 2002). Then it was discovered that this value has an impact on consumer pleasure and motivates consumer behavior intentions (Zeithaml 1988; Babakus and Boller, 1992; Sanjaya and Yasa, 2018). Quality products, according to Sukaatmaja and Yasa (2020), lead to people's satisfaction and, as a result, consumer loyalty. Repeat purchases and the delivery of positive information to friends or family are two indications of loyalty (Saraswita and Yasa, 2017; Putra and Yasa, 2017; Riasma et al., 2018; Rasmiati and Yasa, 2019; Muderawan et al., 2020; Diputra dan Yasa, 2021). The same thing was also conveyed by Imrie et al., (2002) Some examples of behavioral intentions that are motivated by service quality assessments are word of mouth (WOM) and repurchase intention.

Word-of-mouth (WOM) has been recognized as one of the most influential resources in conveying information and recommending a product. WOM is a consumer's post-purchase intention that occurs when consumers share their experiences and impressions when consuming services (Leonard, 2017; Heryana and Yasa, 2020). Currently, with the advancement of information technology and the use of the internet, it has grown rapidly so that online sites and social networks have emerged which have now changed the paradigm and method of delivering information through internet media or also known as electronic Word of Mouth (e-WOM) in Jalilvand (2012). ). This phenomenon allows consumers to engage in communication such as posting text reviews, product images, videos, and product recommendations so that it has an impact on consumers because the information that is easily accessible via the internet can greatly influence consumer consumption decisions or their intention to buy the product again (repurchasing intention).

In order to maintain the existence of Ubud as the destination of choice in Bali, and with the current global destination competition, a study is needed to help tourism practitioners understand the relationship between the three variables, namely destination quality, brand image / image and e-WOM on revisit intentions. Many studies have revealed that the relationship is only limited to visiting intentions, therefore it is necessary to combine research that contains three variables directly, namely; destination quality, brand image/image and e-WOM on intention to return to Ubud, as well as the mediating role of image and e-WOM that affect destination quality on revisit intention to Ubud.

\section{Literature Review}

\subsection{Tourist Destinations}

A tourist destination is a combination of tourism products, services, and public goods that are all consumed under the same brand name, resulting in a consistent integration for visitors. The attractiveness and experience of a destination can be molded by numerous variables such as attractions, facilities, accessibility, human resources, image, and pricing, according to (Tuohino \& Konu, 2014) in (Hidayah, 2019).

\subsection{Service Quality}

Service quality is defined as a consumer's subjective assessment of the overall superiority of an entity/organization, resulting from a comparison of expectations with perceived performance (Parasuraman et al., 1988). Quality measurement at this destination is adapted from the Servqual model (Parasuraman et al., 1988) which is also mentioned in (Bhawarna et. al., 2013; Wiratama et al., 2017) which is a very popular model used in service marketing research. (Kapiki, 2011) mentions that servqual is one of the most popular models to measure service quality in the hospitality industry. Service quality consists of five dimensions to measure consumer perceptions of service quality, namely; tangible, empathy, reliability, responsiveness and assurance.

\subsection{Quality in Tourism}

In the tourist and hospitality sector, quality refers to the consistent delivery of guest products and services that meet or exceed expectations. One of the most significant issues that hospitality managers/stakeholders will 
confront is providing quality service, which is a necessary prerequisite for success in the rapidly increasing and highly competitive global hospitality business. Tourism Destination Quality, namely: "the result of a process that implies the satisfaction of all tourism products and services required, requirements and expectations of consumers at an acceptable price in accordance with the terms of a mutually accepted contract and implicit underlying factors such as safety and security, cleanliness, accessibility, communication, infrastructure, and public facilities and services. It also involves ethical aspects, transparency and respect for the human, natural and cultural environment" World Tourism Organization (2017).

\subsection{Brand Image}

The main driver of brand equity is brand image, which relates to consumers' overall views and feelings about a brand and has an impact on their behavior (Zhang, 2015; Mira and Yasa, 2015; Sari and Yasa, 2019; Asdiana and Yasa, 2020; Gita et al. al., 2020). According to Hsieh, et al., (2004) in Mathur and Nathani (2016), a strong brand image enables customers to identify requirements that may be met by a brand and to distinguish the brand from its competitors, hence expanding the options and possibilities for consumers to purchase products. The image of a destination is a critical factor in making a destination decision (Bonn, et. al., 2005) in (Tosun, et.al. 2015). Then it is stated that in addition to influencing the decision to choose a destination, the image of a destination also affects the intention to visit again (Kandampully et.al, 2011).

\subsection{Electronic Word of Mouth (e-WOM)}

Word of mouth is one of the oldest forms of communication delivery (Dellarocas, 2003) oral person-to-person communication / verbal communication between individuals to other individuals or between the sender and recipient of the message which includes elements of a product, service or brand (Arndt, 1967) mentioned in HueteAlcocer (2017). Then in Jalilvand (2012) it is stated that word of mouth has been known as one of the most influential sources of information transmission. Technological advances and the emergence of online social networking sites have changed the way information is delivered, and this phenomenon has an impact on consumers because this easily accessible information can greatly influence consumption decisions. Then Hennig-Thurau et.al., (2004) in (Jalilvand, 2012) states that electronic word of mouth (e-WOM) is a positive or negative statement made by real and potential consumers about a product or company that allows it to be shared. access by the general public and institutions through the internet. Negative theory argues that negative eWOM is more easily absorbed by visitors than positive eWOM; as a result, negative eWOM may have a bigger negative impact on travel and revisit intention. On the plus side, acquiring new tourists costs five times more than keeping existing visitors (Yeoh et al., 2015). Electronic Word of Mouth (e-WOM) messages can successfully lower the risks and uncertainties that customers face when purchasing items or services, affecting their buying intentions and decision making (Chartterjee, 2001). (Bambauer-Sachse and Mangold, 2011; Asdiana and Yasa, 2020).

\subsection{Revisit Intention}

Revisit intention to a destination is referred to as the intention to visit again. Because visitor retention costs are substantially lower than acquiring new visitors (Um et al., 2006 in Abubakar et al., 2017), destination marketers are interested in learning what motivates tourists to return (2016). According to Chen and Tsai (2007), behavioral intention is defined as a tourist's decision to return to the same tourist location or be inclined to suggest it to others. Then (Han \& Kim, 2010) in Stylos, et al., (2016) and Adinegara et al. (2017), states that the intention to return to a tourist destination is defined as individual readiness and willingness to repeat visits to the same destination.

\subsection{Hypothesis and Conceptual Framework for Research}

The quality of Ubud destinations is indicated to have a direct influence on the brand image, revisit intention and e-WOM Ubud. Brand image and e-WOM are also indicated to have an effect on revisit intention. As well as the role of brand image and e-WOM in mediating the relationship between destination quality and revisit intention. The conceptual framework of the research is shown in Figure 1 below: 


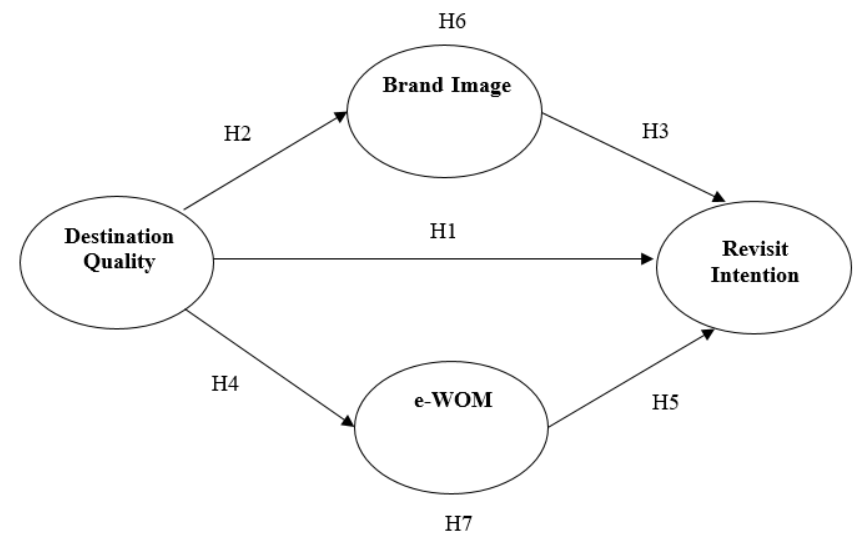

Figure 1. Conceptual Framework for Research on the Effect of Destination Quality of Ubud on Brand Image, eWOM and Revisit Intention

The research hypothesis is formulated as follows, based on the theoretical concepts and empirical findings described:

\section{Effect of destination quality on revisit intention to Ubud}

Baker and Crompton (2000) in their research use satisfaction and service quality as a measure of revisit intention. It was found that perceived service quality has been shown to be a good predictor of tourist intention to revisit the annual festival (visitors future behavioral intention). In research (Timur, 2018) it is stated that there is a significant and positive relationship between service quality and revisit intention to the thermal tourism business. This study measures the quality of a tourist destination, namely Ubud, where the research variable adapts the service quality model using Servqual. So the first hypothesis is formulated as follows:

H1 : Destination quality has a positive and significant effect on revisit intention to Ubud

\section{Effect of destination quality on Ubud's brand image}

Ditcher (1985) in his research on the concept of image reveals that image perception does not only come from the individual or the quality of a product but is also influenced by the opinions of others. Meanwhile, Aydin and Ozer (2005) in their research revealed that consumer perceptions of the quality of a product directly affect the image of the product. Similar research was conducted by Setyadi et al., (2017); Malik et al., (2012) who found that quality has a positive and significant effect on brand image partially. Based on this research, the second hypothesis can be formulated:

$\mathrm{H} 2$ : The quality of the Ubud destination has a positive and significant effect on the Ubud's brand image

\section{Effect of brand image on revisit intention to Ubud}

Many studies have been conducted on the effect of destination image on the choice of tourist destinations and the intention to return (Chen and Tsai, 2007; Kamenidou, et al, 2009; Som, et al., 2012; Abubakar and Ilkan, 2016). Then Som and Badarneh (2011) in their research on tourist satisfaction and return visits, state that destination image is a determining factor that can have a significant effect on satisfaction and revisit intention. Destination image has a major contribution to the Revisit Intention of tourists to come to these tourist attractions, the decision of the Revisit Intention of tourists is very influential on the image of the destination owned by a particular tourist spot in Iran (Abubakar and Ilkan, 2016). Destination image also has an effect on post-purchase evaluation and affects behavior such as perceived value, intention to revisit and willing to recommend it to others (Chen and Tsai, 2007; Adinegara et al., 2017). Based on this research, the hypotheses tested are:

H3 : The image of Ubud has a positive and significant effect on revisit intention to Ubud

\section{Effect of the destination quality on the electronic Word of Mouth (e-WOM)}

Parasuraman et al., (1994) revealed that many studies that discussed service quality stated that customer satisfaction was formed from service quality. A positive and significant relationship between tourist satisfaction with promoting was found in the research of Hulkman et al., (2012). In their research, Saodin et al., (2019) revealed that e-service quality has a significant impact on electronic word of mouth, a study on consumers at three-star hotels in Lampung. In other related studies also indicate that an e-WOM message has an important meaning for a consumer in obtaining information about the quality of a product or service (Chevalier and Mayzlin, 2006). This will be an important source of reference for consumers in building the decision-making process. The tested hypotheses are:

H4 : Destination quality has a positive and significant effect on the electronic Word of Mouth (e-WOM) 


\section{Effect of electronic Word of Mouth (e-WOM) on revisit intention to Ubud}

Jalilvand and Samiei (2012) state that e-WOM is very influential on the selection of tourist destinations. Vermeulen and Seegers (2009) conducted a study of 168 respondents to determine the impact of online reviews on tourist behavior in choosing hotels. The study revealed that positive online reviews can encourage tourist behavior towards decision making in choosing a hotel. In Prayogo and Kusumawardhani's research (2017) e-WOM has a significant impact on the intention to return to a tourist destination. The information they get from the internet for e-WOM can attract the attention of visitors because it is easy and practical. In the modern era, a good destination image and good quality of service are not enough, e-WOM has proven to be a low cost effective way to promote a tourism site. Based on these empirical studies, the fifth hypothesis can be formulated:

H5 : Electronic Word of Mouth (e-WOM) Ubud has a positive and significant effect on revisit intention to Ubud.

The role of brand image in mediating the influence of destination quality on revisit intentions to Ubud

As a consequence of the conceptual framework model of the research that has been described previously, the next hypothesis can also be drawn, namely the role of image in mediating the influence of destination quality on the intention to return to Ubud.

H6: Image significantly mediates destination quality on revisit intentions to Ubud.

\section{The role of electronic word of mouth (e-WOM) in mediating the effect of destination quality on revisit intentions to Ubud}

Then the last hypothesis which is also a consequence of the research concept framework model is the role of electronic Word of Mouth (e-WOM) in mediating the influence of destination quality on the intention to return to Ubud.

H7: Electronic Word of Mouth (e-WOM) significantly mediates the destination quality on the revisit intentions to Ubud.

\section{Research Method}

This research is an explanatory research, where in explaining the relationship between variables is done through hypothesis testing. This research was conducted in June 2021 with the predictor variable (X) in this study is the quality of the destination and the response variable $(\mathrm{Y})$ in this study is the brand image/image and e-WOM and the intention to visit again. The population in this study were 156 respondents of domestic tourists who had visited Ubud at least once in the last 3 years. The number of samples is determined using the formula $4 \mathrm{x}$ the number of indicator variables. Determination of the sample in this study is non-purposive sampling, so there are questions that function as a filter at the beginning of the questionnaire.

The questionnaire is divided into four sections: first, a statement identifying the destination's quality and its five dimensions, which is measured by fifteen indicators; second, a statement identifying the image / brand image, which is measured by three indicators; third, a statement identifying electronic word of mouth, which is measured by five indicators; and fourth, a statement identifying the intention to return, which is measured by three indicators. A Likert scale was used to rate the statements, with 1 indicating strong disagreement and 5 indicating strong agreement. The study instruments' validity and reliability were examined. The Partial Least Square (PLS) method was utilized to analyze the data in this study.

\section{Data Analysis}

\subsection{Characteristics of Respondents}

The majority of respondents $(34 \%)$ were in the age range of 24 to 32 years, followed by respondents in the age range of 32 to 40 years $(30.1 \%)$, respondents in the age range of 40 years $(23.1 \%)$, and finally respondents in the age range of 16 to 32 years $(23.1 \%)$. By 12.8 percent in 24 years. In terms of gender, female respondents account for 62.2 percent of the total, while male respondents account for $37.8 \%$. According to respondents' education statistics, the majority of respondents have a last education level of S1, accounting for 62.8 percent of the total. Then followed by respondents with the last educational level of Diploma/equivalent, which was 16 percent, then respondents with the last education level of SMA/Vocational School with a total percentage of 10.9 percent and respondents with the last education level Postgraduate having the smallest number, namely 10.3 percent. Based on data on the type of work, the majority of respondents' types of work are private employees with a total percentage of 54.5 percent. Then followed by respondents with other types of work by 17.3 percent, followed by respondents with professional types of work (Doctors, Lecturers, Consultants, Lawyers) with a total of 12.2 percent. Furthermore, respondents with the type of work are self-employed with a total of 9 percent, students/students with a total percentage of 5.1 percent and the last is civil servants with a total of 1.9 percent. 


\subsection{Evaluation of the outer reflective indicator model Convergent validity test}

The average variance extracted (AVE) value in each variable reveals convergent validity. All of the variables given in Table 1 have an average variance extracted (AVE) value greater than 0.5 in this study, indicating that they all meet the convergent validity criterion. The results of this test reveal that all indicators are legitimate and feasible indicators for measuring the variables in question.

Table 1. Convergent Validity Test Results

\begin{tabular}{|l|l|}
\hline Variable & AVE \\
\hline Destination Quality (X) & 0.598 \\
\hline Brand Images (Y1) & 0,738 \\
\hline Electronic Word of Mouth (Y2) & 0,739 \\
\hline Revisit Intention (Y3) & 0,673 \\
\hline
\end{tabular}

\section{Discriminant validity test}

A discriminant validity test is used to ensure that the idea of each latent variable is distinct from that of other variables. The model is said to have excellent discriminant validity if each loading indicator value of a latent variable has a loading value that is greater than the loading value of the correlation with other hidden variables (Cross Loading). In this scenario, it is recommended that the measurement value be more than 0.50 . Table 3 shows that all cross loading values for each indication in each variable are more than 0.5 . As a result, the study's findings can be trusted.

Table 2. Discriminant Validity

\begin{tabular}{|l|l|l|l|l|}
\hline & Brand Image & $\begin{array}{l}\text { Electronic Word } \\
\text { of Mouth }\end{array}$ & $\begin{array}{l}\text { Destination } \\
\text { Quality }\end{array}$ & $\begin{array}{l}\text { Revisit } \\
\text { Intention }\end{array}$ \\
\hline Brand Image & 0.859 & & & \\
\hline Electronic Word of Mouth Ubud & 0.523 & 0.860 & & \\
\hline Destination Quality Ubud & 0.604 & 0.551 & 0.773 & 0.878 \\
\hline Revisit Intention & 0.488 & 0.461 & 0.478 \\
\hline
\end{tabular}

Composite Reliability

A group of indicators that measure a variable's composite reliability is referred to as composite reliability. Internal consistency is measured by Composite Reliability, which must be greater than 0.60 and have a Cronbach alpha value greater than 0.70 , according to the Chin method. Table 3 reveals that the composite reliability coefficient value is greater than the threshold, i.e. $>0.70$, implying that this study has strong dependability on each variable. Table 3. Coefficient of Composite Reliability and Cronbach's Alpha

\begin{tabular}{|l|l|l|}
\hline Variable & Composite Reliability & Cronbach's Alpha \\
\hline Brand Image & 0.894 & 0.823 \\
\hline Electronic Word of Mouth & 0.934 & 0.911 \\
\hline Kualitas Destinasi & 0.881 & 0.831 \\
\hline Revisit Intention & 0.857 & 0.745 \\
\hline
\end{tabular}

\subsection{Inner model evaluation}

The direct influence significance test, indirect effect testing, and evaluation of the influence of each exogenous variable on endogenous variables are all part of the inner model test. The R-Square, significance value, and research hypotheses from the research model will be tested using all of these tests.

\section{R- square}

Shows the strength and weakness of the influence that arises from the variation of exogenous variables on endogenous variables. In Ghozali (2012) it is stated that the R-Square (R2) value of 0.75 is classified as a strong model, while the R-Square (R2) value of 0.50 is classified as a moderate model and the R-Square (R2) value is 0 . 25 is a weak model.

Table 4. Value of R-square (R2)

\begin{tabular}{|l|l|l|}
\hline Variable & R Square & R Square Adjusted \\
\hline Brand Image $\left(\mathrm{Y}_{1}\right)$ & 0.365 & 0.361 \\
\hline Electronic Word of Mouth $\left(\mathrm{Y}_{2}\right)$ & 0.304 & 0.299 \\
\hline Revisit Intention $\left(\mathrm{Y}_{3}\right)$ & 0.321 & 0.307 \\
\hline
\end{tabular}

Table 4 shows that the R-square (R2) value of all variables is less than 0.50 , indicating that it meets the weak criteria. The R-square (R2) Brand Image variable (Y1) has a value of 0.365 . This number explains why only 36.5 percent of changes in Brand Image (Y1) in this study are driven by external variables, while 63.5 percent are influenced by variables outside the model. Furthermore, the Electronic Word of Mouth Ubud variable (Y2) has an 
R-square (R2) value of 0.304. Only 30.4 percent of changes in Electronic Word of Mouth Ubud (Y2) are impacted by exogenous variables in this study, while 69.6 percent of changes in Electronic Word of Mouth Ubud (Y2) are influenced by exogenous variables. Ubud (Y2) are influenced by exogenous variables in this study, while 69.6\% changes in Electronic Word of Mouth Ubud (Y2) are influenced by variables outside the model. The R-square value (R2) of the Revisit Intention (Y3) variable is 0.321 . This value can explain that only $32.1 \%$ of changes in Revisit Intention (Y3) are influenced by exogenous variables in this study, while $67.9 \%$ changes in Revisit Intentions (Y3) are influenced by variables outside the model.

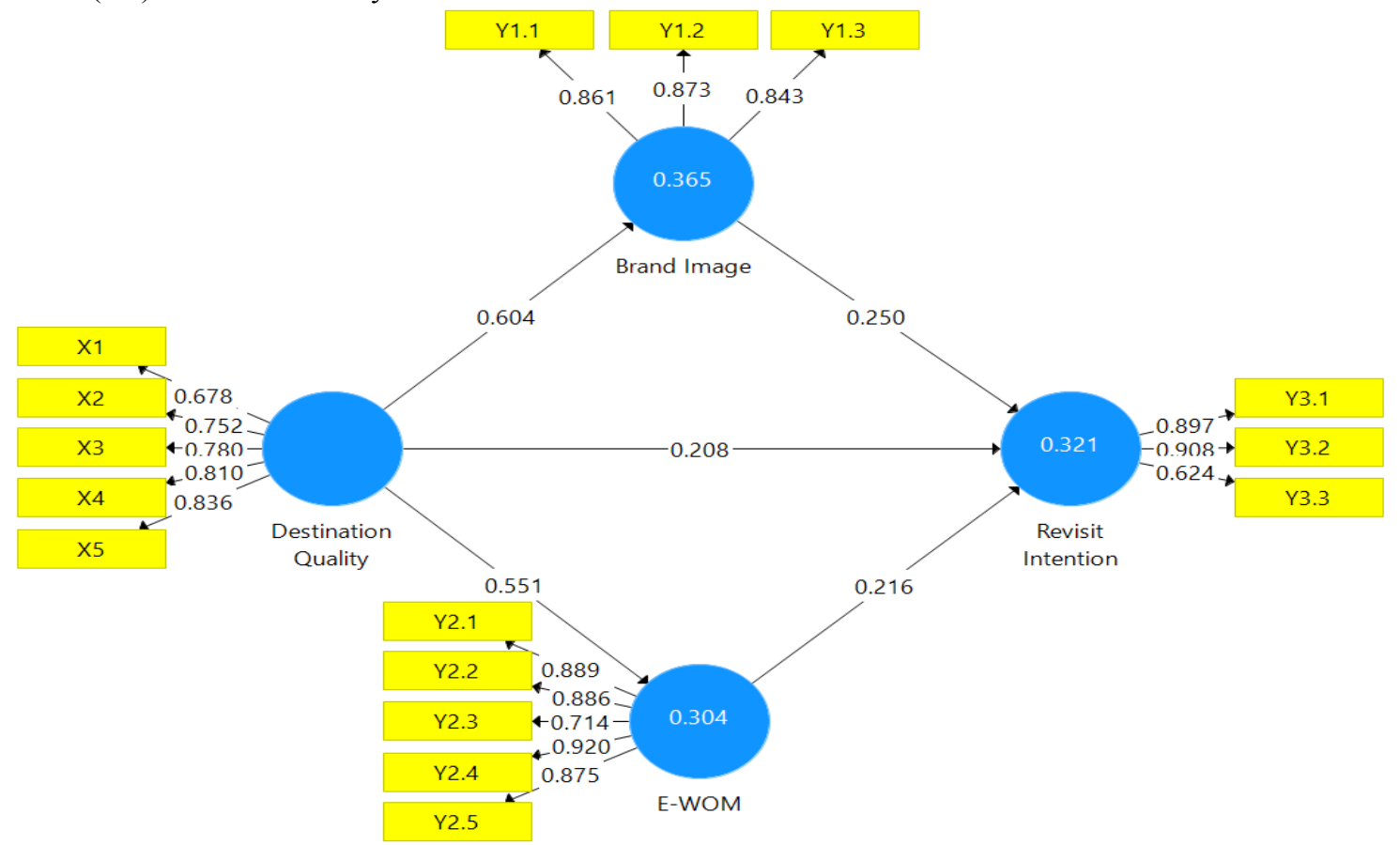

Figure 2 Algorithm Diagram of SEM-PLS Analysis Results

\section{$Q$-square $\left(\mathbf{Q}^{2}\right)$}

The value of Q-square (predictive relevance) has a value with a range of $0<\mathrm{Q} 2<1$, where the closer to 1 means the better the model. The results of these calculations obtained the value of $\mathrm{Q}^{2}$ is 0.706 or 70.6 percent, which means that the model has a good value. Thus, it can be explained that 70.6 percent of the variation in Brand Image (Y1), Electronic Word of Mouth Ubud (Y2) and Revisit Intention (Y3) variables have predictive relevance.

\subsection{Hypothesis testing}

Direct effect test

Hypothesis testing in this study uses a structural equation model from SEM with the Partial Least Square technique using the SmartPLS 3.0 program. The basis used in testing the hypothesis is the value contained in the output path coefficients and the total effects on each path for direct effects as presented in Table 5.

Table 5. Direct Effect Test Results

\begin{tabular}{|l|l|l|l|l|l|l|}
\hline & & $\begin{array}{l}\text { Original } \\
\text { Sample (O) }\end{array}$ & $\begin{array}{l}\text { Sample } \\
\text { Mean (M) }\end{array}$ & $\begin{array}{l}\text { Standard } \\
\text { Deviation } \\
\text { (STDEV) }\end{array}$ & $\begin{array}{l}\text { T Statistics } \\
\text { (O/STDEV|) }\end{array}$ & $\begin{array}{l}\text { P } \\
\text { Values }\end{array}$ \\
\hline H1 & $\begin{array}{l}\text { Destination Quality } \rightarrow \\
\text { Revisit Intention }\end{array}$ & 0,208 & 0,210 & 0,099 & 2,108 & 0,036 \\
\hline H2 & $\begin{array}{l}\text { Destination Quality } \rightarrow \\
\text { Brand Image }\end{array}$ & 0,604 & 0,608 & 0,050 & 12,111 & 0,000 \\
\hline H3 & $\begin{array}{l}\text { Brand Image } \rightarrow \text { Revisit } \\
\text { Intention }\end{array}$ & 0,250 & 0,251 & 0,094 & 2,645 & 0,008 \\
\hline H4 & $\begin{array}{l}\text { Destination Quality } \rightarrow \\
\text { Electronic Word of } \\
\text { Mouth }\end{array}$ & 0,551 & 0,561 & 0,061 & 9,086 & 0,000 \\
\hline H5 & $\begin{array}{l}\text { Electronic Word of } \\
\text { Mouth } \rightarrow \text { Revisit } \\
\text { Intention }\end{array}$ & 0,216 & 0,214 & 0,090 & 2,383 & 0,018 \\
\hline
\end{tabular}


1) Destination Quality towards Revisit Intention has t statistic of $2.108>\mathrm{T}$-table (1.96), and P value of 0.036 , because $\mathrm{P}$ values $<0.05(0.036<0.05)$ then the hypothesis is accepted. Thus this shows that the Destination Quality of Ubud with its indicators has a positive and significant effect on Revisit Intention with its indicators. Then it can be seen from the value of the path coefficient that is positive at 0.208 and it also means that the higher the Destination Quality of Ubud, the higher tourist Revisit Intention.

2) The Destination Quality of Ubud on the Brand Image has t statistic of 12.111, and P value of 0.000 , because $\mathrm{P}$ values $<0.05(0.000<0.05)$ then the hypothesis can be accepted. This shows that there is a positive and significant effect between Ubud Destination Quality on Ubud Brand Image which can be seen in the path coefficient of 0.604 which is positive, because the positive path coefficient value means that the Ubud Destination Quality is positive on the Ubud Brand Image. This means that the higher the quality of the Ubud Destination, the more capable it is to improve the Ubud Brand Image.

3) Ubud's Brand Image on Revisit Intention has t-statistic value of 2.645, and P-value of 0.008, because P values $<0.05(0.008<0.05)$, the hypothesis can be accepted. This shows that there is a significant influence between the Ubud Brand Image on Revisit Intention. Seen from the positive value of the path coefficient of 0.250, it can be interpreted that the higher the Ubud Brand Image, the higher tourist Revisit Intention.

4) The Destination Quality of Ubud on the Electronic Word of Mouth has t statistic of 9.086, and P value of 0.000 , because $\mathrm{P}$ values $<0.05(0.000<0.05)$ then the hypothesis can be accepted. This shows that there is a positive and significant influence between the Quality of Ubud Destinations on Electronic Word of Mouth which can be seen in the path coefficient of 0.551 which is positive, because the path coefficient value is positive, meaning that the Quality of Ubud Destinations is positive on Electronic Word of Mouth. This means that the higher the quality of the Ubud Destination, the better the Electronic Word of Mouth.

5) Electronic Word of Mouth on Revisit Intention has a t statistic of 2.383, and P value of 0.018, because $P$ values $<0.05(0.018<0.05)$ then the hypothesis can be accepted. This shows that there is a positive and significant influence between Electronic Word of Mouth Ubud on Revisit Intention which can be seen in the path coefficient of 0.216 which is positive, because the path coefficient value is positive, meaning Electronic Word of Mouth Ubud is positive on Revisit Intention. This means that the better the Electronic Word of Mouth, the higher tourist Revisit Intention.

\section{Indirect effect test}

If the $\mathrm{VAF}$ value is above $80 \%$, then it indicates a full mediation role (full mediation). If the VAF is between $20 \%$ $-80 \%$ then it can be categorized as partial mediation. However, if the VAF is less than $20 \%$, it means that there is no mediating effect. Examination of the mediating variables in this study will examine the mediating role of the Ubud Brand Image and Electronic Word of Mouth Ubud variables on the indirect effect of Ubud Destination Quality on Revisit Intention.

Menghitung nilai VAF dengan rumus:

$\mathrm{VAF}=$ indirect effect

Total effect

Table 6. Indirect Effect Test Results

\begin{tabular}{|l|l|l|l|l|l|l|}
\hline & & $\begin{array}{l}\text { Original } \\
\text { Sample (O) }\end{array}$ & $\begin{array}{l}\text { Sample } \\
\text { Mean (M) }\end{array}$ & $\begin{array}{l}\text { Standard } \\
\text { Deviation } \\
(\text { STDEV })\end{array}$ & $\begin{array}{l}\text { T Statistics } \\
(|\mathrm{O} / \mathrm{STDEV}|)\end{array}$ & $\begin{array}{l}\mathrm{P} \\
\text { Values }\end{array}$ \\
\hline H6 & $\begin{array}{l}\text { Destination Quality } \rightarrow \text { Brand } \\
\text { Image } \rightarrow \text { Revisit Intention }\end{array}$ & 0,151 & 0,152 & 0,058 & 2,620 & 0,009 \\
\hline H7 & $\begin{array}{l}\text { Destination Quality } \rightarrow \\
\text { Electronic Word of Mouth } \rightarrow \\
\text { Revisit Intention }\end{array}$ & 0,119 & 0,120 & 0,053 & 2,227 & 0,026 \\
\hline
\end{tabular}

1) Brand Image is able to mediate positively on the indirect effect of Destination Quality on Revisit Intention. These results are shown from the mediation test that was carried out producing a t statistic value of 2.620, and a $\mathrm{P}$ value of 0.009 , because $\mathrm{P}$ values $<0.05(0.009<0.05)$, then seen from the path coefficient value positive value of 0.151 , the hypothesis can be accepted.

$\mathrm{VAF}=\frac{\text { indirect effect }}{\text { Total effect }}$

$$
\begin{gathered}
\mathrm{VAF}=0,151 \quad=0,151 \\
0,208+(0,151) \\
\mathrm{VAF}=0,421=42,1 \%
\end{gathered}
$$

The VAF value of $42.1 \%$ indicates that the Ubud Brand Image has a partial mediating effect on the Quality of Ubud Destinations on Revisit Intention. 
2) Electronic Word of Mouth Ubud is able to positively mediate the indirect effect of Ubud Destination Quality on Revisit Intention. These results are shown from the mediation test that was carried out producing a t statistic value of 2.227 , and a $\mathrm{P}$ values of 0.026 , because $\mathrm{P}$ values $<0.05(0.026<0.05)$, then seen from the path coefficient value positive value of 0.119 , the hypothesis can be accepted.

$\mathrm{VAF}=$ indirect effect

$$
\begin{aligned}
& \text { Total effect } \\
& \mathrm{VAF}=0,119 \\
& 0,2 \overline{08+(0,119)}
\end{aligned}=\frac{0,119}{0,327}
$$

$\mathrm{VAF}=0,364=36,4 \%$

The VAF value of $36.4 \%$ indicates that Electronic Word of Mouth Ubud has a partial mediating effect on the Quality of Ubud Destinations on Revisit Intention.

\section{Discussion}

The path coefficient of Ubud Destination Quality towards Ubud Brand Image is 0.604 and has a t statistic of 12.111 . The path coefficient shows that Ubud Destination Quality has a positive influence on the Ubud Brand Image. Thus this shows that the higher the quality of the Ubud Destination, the more capable it is to improve the Ubud Brand Image. This presentation is in line with several previous studies, namely the research conducted by Okeudo (2013) and Aspizain (2016) which used the five dimensions of Service Quality, finding a very significant influence between Service Quality on Brand Image in their research on the aviation industry. Setyadi (2017) who found that there was a positive and significant relationship between Service Quality and Brand Image in his research on the retail industry.

The path coefficient of the Ubud Brand Image to Revisit Intention is 0.250 and has a t statistic of 2.645. The path coefficient shows that the Ubud Brand Image has a positive influence on Revisit Intention. Thus, this shows that the higher the Ubud Brand Image, the more capable it is to increase the Revisit Intention. This explanation is in line with previous research conducted by Sudarmiatin (2019) and Prabowo, et.al (2020) which stated that destination image had a positive and significant effect on revisit intention. In addition, Destari (2017) in his research also mentions that destination image has a positive and significant effect on the intention to return to the tourism industry. Destination image plays an important role in creating revisit intentions because tourists will decide to revisit a destination influenced by the image they want to highlight from the products offered. This is also in accordance with the Ubud Brand Image indicator which received the highest score in the table, namely the indicator "Ubud has a unique reputation based on culture".

The path coefficient of Ubud Destination Quality towards Electronic Word of Mouth Ubud is 0.551 and has a $t$ statistic of 9.086. The path coefficient shows that Ubud Destination Quality has a positive influence on Electronic Word of Mouth Ubud. Thus, this shows that the higher the quality of the Ubud Destination, the more capable it is to improve the Electronic Word of Mouth Ubud. This explanation is in line with several previous studies, namely Prabowo, et.al (2020) which in their research found that Service Quality had a positive and significant effect on Electronic Word of Mouth. Uslu (2020) who found that there was a significant relationship between Service Quality and Revisit Intention in his research on a local restaurant business in Diyarbakır - Turkey.

The coefficient of the Electronic Word of Mouth Ubud path to Revisit Intention is 0.216 and has a t statistic of 2.383. The path coefficient shows that Electronic Word of Mouth Ubud has a positive effect on Revisit Intention. Thus, this shows that the higher the Electronic Word of Mouth Ubud, the more capable it is to increase the Revisit Intention. This explanation is in line with several previous studies, namely Prabowo, et.al (2020) which stated that the Word of Mouth had a positive and significant effect on revisit intention in budget hotel Airy Rooms. In addition, a similar study was also conducted by Kitapci, et.al (2014) which stated that the word of mouth had a positive and significant effect on repurchase intention in the public health industry in Turkey.

The Ubud Brand Image path coefficient on the indirect effect of Ubud Destination Quality on Revisit Intention is 0.151 and has a t-statistic value of 2.620. The path coefficient shows that the Ubud Brand Image has a positive influence in mediating the Quality of Ubud Destinations on Revisit Intentions. Thus, this shows that the higher the Ubud Brand Image, the more capable it is to increase the indirect effect of Ubud Destination Quality on Revisit Intention. This presentation is in line with previous research, namely Ardila's research (2017) which states that Brand Image has a positive and significant effect on the relationship between service quality and Revisit Intention.

The path coefficient of the Electronic Word of Mouth Ubud on the indirect effect of Ubud Destination Quality on Revisit Intention is 0.119 and has a t-statistic value of 2.227. The path coefficient shows that Electronic Word of Mouth Ubud has a positive influence in mediating the Quality of Ubud Destinations on Revisit Intentions. Thus, this shows that the higher the Electronic Word of Mouth Ubud, the more capable it is to increase the indirect effect of Ubud Destination Quality on Revisit Intention. This presentation is in line with several previous studies, namely Liu and Lee's (2016) research on the airline industry and Prabowo, et.al (2020) research on the hotel industry which states that Word of Mouth has a positive and significant effect in mediating service quality on revisits 
intention.

\section{Implications, Limitations, and Future Research}

The findings of this study contribute to the existing literature, especially regarding destination quality, brand image, electronic Word of Mouth (e-WOM) and intention to return to Ubud. This study not only empirically examines the direct relationship but also the mediating effect between the selected variables. This study uses image (brand image) and electronic Word of Mouth (e-WOM) as mediating variables. This study is expected to provide empirical evidence of implications, and theoretically to expand on previous studies that examined the effect of Ubud destination quality, Ubud brand image, electronic Word of Mouth (e-WOM) Ubud and intention to return to Ubud and the influence of indirectly mediated by the variable image (brand image) and electronic Word of Mouth (e-WOM). In addition, this research is also expected to contribute to the development of marketing management science, especially with regard to the variables in this study that can have a positive and negative influence between exogenous and endogenous variables and their significance on revisit intention to a destination. The results of this study are expected to provide consideration for policy makers regarding the management of Ubud as a tourist destination, in an effort to maintain the Ubud tourist destination as a quality destination so that it can maintain the title achieved and be able to compete with other international tourist destinations.

This research has been attempted and carried out in accordance with scientific procedures, however, there are still limitations that need to be underlined, especially for further research. This research only relies on the results of questionnaires distributed via google forms, due to the Covid-19 pandemic which makes it impossibility to distribute questionnaires directly and conduct interviews with respondents to get maximum results. The scope of this research is only aimed at domestic tourist respondents due to the Covid-19 pandemic which makes it impossible for foreign tourists to visit at this time. So to complete this research, it is hoped that further research can be carried out on foreign tourists to be able to find out their opinions about Ubud destinations internationally.

\section{References}

Abubakar, A. M., and Ilkan, M, 2016. "Impact of online WOM on destination trust and intention to travel: A medical tourism perspective". Journal of Destination Marketing and Management, pp. 1-10.

Abubakar, A. M., Ilkan, M and Al-Tal, Raad M. 2017. "eWOM, revisit intention, destination trust and gender". Journal of Hospitality and Tourism Management, pp. 220-227.

Adinegara, IPG N. J. Suprapti, N.W.S., Yasa, N.N.K., 2017, Factors That Influences Tourist's Satisfaction and its Consequences, European Journal of Business and Management, pp. 39-50

Adinegara, J, Suprapti, N.W.S., Yasa, N.N.K., Sukaatmadja, I P.G., 2018, Antecedents And Consequences Of Tourist Satisfaction: A Literature Review, ASEAN Marketing Journal, pp. 40-53

Ardila, Niela. 2017. "The Effect Of Service Quality On Revisit Intention With Customer Satisfaction And Brand Image As Mediating Variable In Eco Green Park, Batu, East Java”. Fakultas Ekonomi dan Bisnis Universitas Brawijaya

Asdiana, LDP and Yasa, N.N.K., 2020, The Role of Image Brands Mediates e-WOM Effects on Buying Interest in Triton Learning Institutions, Russian Journal of Agricultural and Socio-Economic Sciences, Vol. 7, No. 103 , pp. $45-53$

Aspizain, Chaniago. 2016. "The Effects of Service Quality and Corporate Rebranding on Brand Image, Customer satisfaction, Brand Equity and Customer Loyalty: Study in advertising company at TV One". Russian Journal of Agricultural and Socio-Economic Sciences, pp. 209-217

Atilgan, Eda. Serkan Akinci and Safak Aksoy, 2003. "Mapping service quality in the tourism industry", Managing Service Quality, Vol. 13, No5, pp. 412-422.

Aydin, S. and Ozer, G. 2005. "The analysis of antecedents of customer loyalty in Turkish mobile telecommunication market”, European Journal of Marketing, Vol. 39 No. 7/8, pp. 910-25.

Babakus, E. Dan Boller, G.W. 1992. "An empirical assesment of the SERVQUAL scale”, Journal of Business Research, Vol. 24, pp. 253-68.

Badan Pusat Statistik Provinsi Bali. 2019. “Bali dalam angka 2019”, BPS Provinsi Bali.

Badan Pusat Statistik. 2020. https://bali.bps.go.id

Baker, Dwayne A., and Crompton, John L. 2000. "Quality, Satisfaction and Behavioural Intentions", Annals of Tourism Research, Vol.27, No. 3, pp. 785-804.

Bambaueur-Sasche, Silke, Mangold, Sabrina. 2011. "Brand equity dilution through negative online word-ofmouth communication", Journal of retailing and consumer service, No.18, pp. 38-45.

Bhakuni, Pooja., Sneha Rajput, Bhuvanesh Kumar Sharma and S.S. Bhakar. 2021. "Relationship between Brand Image and Store Image as drivers of Repurchase Intention in apparel stores". Gurukul Business Review. Vol. 17, pp. 63-73

Bharwana, Tariq Khalil, Bashir, Mohsin and Mohsin, Muhammad. 2013. "Impact of Service Quality on Customers' Satisfaction: A Study from Service Sector especially Private Colleges of Faisalabad, Punjab, Pakistan”, 
International Journal of Scientific and Research Publications, Vol. 3

Canny, Ivyanno dan Hidayat, Nila. 2012. "The influence of service quality and tourist satisfaction on future behavioural intentions: the case study of Borobudur temple as a UNESCO world culture heritage destination", IEDRC Hongkong Conferences, October 2012.

Chevalier, Judith A., Mayzlin. 2003. "The effect of wourd of mouth on sales", NBER Working Paper No. 10148.

Chen, Ching-Fu. DungChun Tsai. 2007. "How destination image and evaluative factors affect behavioral intentions?", Tourism Management, vol. 28, pp. 1115-1122.

Conde Nast Traveller. www.cntraveler.com

Davis, D.F., Golicic, S.L. and Marquardt, A. 2009. "Measuring brand equity for logistics services", International Journal of Logistics Management, Vol. 20 No. 2, pp. 201-12.

Destari, Fajar. 2017. "Meningkatkan Intention to revisit melalui keunikan jasa pariwisata \& destinasion image: studi kasus pada big event JFC". Jurnal Manajemen dan Kearifan Lokal Indonesia, Vol. 1 No. 1, pp. 44-58

Diputra, IGNAW M. and Yasa, N.N.K., 2021, The Influence Of Product Quality, Brand Image, Brand Trust On Customer Satisfaction And Loyalty, American International Journal Of Business Management, Vol. 4, No. 1, pp. 25-34

Evirasanti, M, Rahyuda, K., and Yasa, N.N.K., 2018, Pengaruh Kualitas Makanan, Kualitas Layanan dan Lingkungan Fisik Terhadap Kepuasan dan Behavioral Intentions (Studi Di Métis Restaurant), E-Jurnal Ekonomi dan Bisnis, Universitas Udayana, Vol. 5, No. 12.

Ghozali, Imam. 2016. "Structural Equation Modeling: Metode Alternatif Dengan Partial Least Square". Semarang: Universitas Diponegoro

Ghozali, Imam and Hengky Latan. 2012. "Partial Least Squares: Konsep, Teknik dan Aplikasi Menggunakan Program SmartPLS 2.0 M3”. Semarang. Badan Penerbit Universitas Diponegoro.

Gita, W.N.M, Yasa, N.N.K., and Rahanata, G.B., 2020, The Role of Brand Image in Mediating The Relationship of Product Quality and Price Fairness with Purchase Decision (A Case Study of the Iphone Product in Denpasar City), SSRG - International Journal of Economics and Management Studies (IJEMS), Vol. 7, No. 4, pp. 199-207

Hellier, Philip K., Geursen, Gus M., Carr, Rodney A., Rickard, John A. 2002, "Customer repurchase intention a general structural equation model”, Journal of Marketing, Vol.37 No. 11/12, pp. 1762-1800.

Hennig-Thurau, Thorsten., Gwinner, Kevin P., Walsh, Gianfranco., and Gremler, Dwayne D. 2004, "Electronic Word-of-Mouth via Consumer-Opinon Platforms: What Motivates Consumers to Articulate Themselves on the Internet?" Journal of Interactive Marketing. Vol.18 No.1, pp.38-52.

Hidayah, Nurdin. 2019. "Pemasaran Destinasi Pariwisata" Penerbit Alfabeta Bandung.

Heryana, D.K. and Yasa, N.N.K., 2020, Effect of Electronic Word of Mouth on Repurchase Intention Mediated by Brand Attitude, International Research Journal of Management, IT \& Social Sciences, Vol. 7, No. 2, pp. 9-20

Huete-Alcocer, Nuria. 2017. "A Literature Review of Word of Mouth and Electronic Word of Mouth: Implications for Consumer Behavior". Front Psychol, Vol. 8, pp. 1256

Hulkman, Magnus., Skarmeas, Dionysis., and Katsikeas, Constantine S. 2012. "Destination personality: effect on satisfaction, identification, word-of-mouth and revisit intentions", UK Academy Conference of Marketing.

Kim, S.H.,Holland,S. and Han,H.-S. 2013. "A structural model for examining how destination image, perceived value, and service quality affect destination loyalty: A case study of Orlando". International Journal of Tourism Research, Vol. 15, No. 4, pp. 313.

Kitapci, Olgun. Akdogan, Ceylan and Drotyol, Ibrahim Taylan. 2014. "The Impact of Service Quality Dimensions on Patient Satisfaction, Repurchase Intentions and Word-of-Mouth Communication in the Public Healthcare Industry". Procedia - Social and Behavioral Sciences, Vol. 148, pp. 161-169

Imrie, Brian C. John W. Cadogan and Rod McNaughton. 2002. "The service quality construct on a global stage", Managing Service Quality, Vol.12, No1, pp.10-18.

Jalilvand, Mohammad Reza. Neda Samiei. 2012. "The impact of electronic word of mouth on a tourism destination choice: Testing the theory of planned behavior", Internet Research Vol. 22, No. 5, pp. 591-612.

Kamenidou, Irene., Mamalis, Spyridon., and Priporas, Contantinos-Vasilios. 2009. "Measuring destination image and consumer choice criteria: the case of Mykonos Island", Tourismos: an International Multidisciplinary Journal of Tourism, Vol. 4, No. 3, pp. 67-79

Kandampully, Jay. Juwaheer, Thanika Devi. Hu, Hsin-Hui. 2011. "The Influence of a Hotel Firm's Quality of Service and Image and its Effect on Tourism Customer Loyalty", International Journal of Hospitality and Tourism Administration, Vol. 12

Kapiki, Soultana. 2011. "Quality Management in Tourism and Hospitality: an Exploratory Study among Tourism Stakeholders". International Journal of Economic Practices and Theories, Vol. 2, No. 2,

Kartajaya, Hermawan and Bembi Dwi Indrio M. 2009, “Ubud The Spirit of Bali”, PT. Gramedia Pustaka Utama Kala, D., and Chaubey, D.S. 2018. Impact of Electronic Word of Mouth on Brand Image and Purchase Intention 
towards Lifestyle Products in India. Pacific Business Review International, Vol. 10, No. 9, pp. 135-144.

Lazar, Ana Florina and Blindheim, Galyna Komolikova. 2016, "Tourist Perceptions and Intention to revisit Norway". Thesis- NTNU: Norwegian University of Science and Technology. Norway

Leonard and Thung, Feby. 2017 " Relationship of service quality, word of mouth and repurchase intention in online transportation service". Journal of Process Management - New Technologies, International. Vol. 5, No. 4

Malik, Muhammad Ehsan. Basharat Naeem and Abdul Mohsin Nasir, 2011. "Impact of service qualityon Brand image: Empirical evidence from hotel industry", Interdisciplinary Journal of Contemporary Research in Business, Vol. 3, No 8, pp. 630-636.

Malik, M. E. Ghafoor, M. M., and Hafiz, K. I. 2012 “Impact of Brand Image, Service Quality and price on customer satisfaction in Pakistan Telecommunication sector". International journal of business and social science, Vol. 3, No. 23

Mathur, Garima and Nathani, Navita. 2016. "Impact of Brand Image on Brand Loyalty in carbonated and nonCarbonated drinks. JIPM, Vol. 1

Mira, N.L.P and Yasa, N.N.K., 2015, Peran Brand Image sebagai Pemediasi Pengaruh Country of Origin pada Brand Equity, Matrik: Jurnal Manajemen, Strategi Bisnis Dan Kewirausahaan, Vol. 9, No. 1

Muderawan, MANW, Rahanata, G.B., and Yasa, N.N.K., 2020, Building Customer Loyalty Through Customer Satisfaction That Influenced By Promotion, Trust and Perceived Ease of Use, American Journal of Humanities and Social Sciences Research, Vol. 4, No. 11, pp. 102-112

Nuseir, Mohammed T. 2019. "The impact of electronic word of mouth (e-WOM) on the online purchase intention of consumers in the Islamic countries - a case of (UAE)", Journal of Islamic Marketing.

Okeudo, Geraldine and David U. Chikwendu. 2013. "Effects of airline service quality on airline image and passengers' loyalty: Findings from Arik Air Nigeria passengers", Journal of Hosptality and Management Tourism. Vol. 4(2), pp. 19-28

Parasuraman, A. Valarie A. Zeithaml and Leonard L. Berry, 1988. "SERVQUAL: A Multiple item scale for measuring customer perceptions of service quality", Journal of Retailing, Vol. 64, No.1, pp. 12-43.

Parasuraman, A. Valarie A. Zeithaml and Leonard L. Berry, 1994. "Reassessment of expectations as a comparison standard in measuring service quality: implications for further research", Journal of Marketing, Vol. 58, pp. 111-124.

Phau, I., Quintal, V., and Shanka, T. 2014. "Examining a consumption values theory approach of young tourist toward destination choice intention". International Journal of Culture, Tourism, and Hospitality Research, Vol. 8 No. 2 , pp. $125-139$

Prayag, Girish. 2009. "Brand image assessment: international visitors' perceptions of Cape Town”, Marketing Intelligence and Planning, Vol. 28 No.4, pp. 462-485.

Prayogo, Rangga Restu and Kusumawardhani, Arinta. 2017 "Examining Relationships of Destination Image, Service Quality, e-WOM, and Revisit Intention to Sabang Island, Indonesia", Asia-Pacific Management and Business Application, Vol. 5, No. 2, pp. 89-102

Prabowo, Heri., Widji Astuti and Harianto Respati. 2020 "Effect of Service Quality and Brand Image on Repurchase Intention through Word of Mouth at Budget Hotels Airy Rooms", Open Journal of Business and Management, Vol. 8, No. 1

Putra I P.A.A and Yasa, N.N.K, 2017, The Role of Corporate Image and Satisfaction in Mediating The Effect of Corporate Social Responsibility on Customer Loyalty, IOSR - Journal of Business and Management, Vol. 9, No. 9, pp. $10-17$

Putra, I K.M. and Yasa, N.N.K., 2014, Pengaruh Kualitas Pelayanan Terhadap Kepuasan Mahasiswa, Citra, dan Positive Word of Mouth Politeknik Negeri Bali, Jurnal Bisnis dan Kewirausahaan, Vol. 1, pp. 90-101

Rasmiati Dwi and Yasa N.N.K., 2019, The Effect of Retail Service and Store Image on Customer Satisfaction And Loyalty In Nirmala Supermarket Jimbaran-Bali, European Journal of Business, Economics and Accountancy, Vol.7, No. 3, 38-52

Riasma, D.K.P., Rahyuda, K. and Yasa, N.N.K, 2018, The Role of Satisfaction and Trust in Mediating The Relationship of Brand Experience and Loyalty, International Journal of Economic, Commerce and Management, Vol. 1, pp. 66-77

Romaniuk, Jenni and Nenycz-Thiel, Magda. 2013. "Behavioral brand loyalty and consumer brand associations", Journal of Business Reseach, Vol. 66, pp.67- 72.

Sanjaya, DPE and Yasa, N.N.K., 2018, The Effect Of Service Quality On Customer Satisfaction, Positive Word Of Mouth And Corporate Image, Journal Of Business And Management, Vol. 20 No. 7, pp. 28-33

Saraswita, P.I. and Yasa, N.N.K., 2017, The Effect of Perceived Justice on Customer Satisfaction and Loyalty at PT Bank BPD Bali, International Journal Multidiciplinary Education And Research, Vol. 2, No. 6, pp. 2025

Sari, AAA Ratih Permata and Yasa, N.N.K., 2019, The Role of Customer Trust as a Mediation on The Effect of 
Corporate Images and Price Fairness to Customer Loyalty, Economic Research, Vol. 3, No. 8, pp. 1-17

Sawitri, N.P., Yasa, N.N.K. and Jawas, A., 2013, Pengaruh Kualitas Pelayanan Terhadap Kepuasan dan Loyalitas Pelanggan Tegal Sari Accommodation di Ubud, Jurnal Manajemen, Strategi Bisnis, dan Kewirausahaan, Vol. 7, No. 1, pp. 40-47

Setyadi, Antonius.Ali, Hapzi and Imaroh, Tukhas Shilul. 2017. "Building Brand Image: Analysis of Service Quality and Customer Satisfaction”. Saudi Journal of Business and Management Studies. Vol. 2, No.8, pp. 770-777

Sholihin, M. and Ratmono, D. 2013. “Analisis SEM-PLS Dengan WarpPLS 3.0”, Edisi Satu, Yogyakarta: Penerbit Andi Offset.

Som, Ahmad Puad Mat., and Badarneh, Mohammad Bader, 2011. "Tourist satisfaction and repeat visitation toward a new comprehensive model", World Academy of Science, Engineering and Technology. Vol. 50, pp. 973980.

Som, Ahmad Puad Mat., Marzuki, Azizan., Yousefi, Maryam., and Abu Khalifeh, Ala'a Nimer. 2012. "Factors influencing visitor revisit behavioral intentions: a case study of Sabah, Malaysia", International Journal Marketing Studies. Vol. 4, No. 4, pp. 39-50.

Stylos, Nikolaos. Vassiliadis, Chris A., Victoria, Bellou and Andronikidis, Andreas. 2016. "Destination Images, Holistic Images and Personal Normative Beliefs: Predictors of Intention to Revisit a Destination", Elsevier Tourism Management, pp. 41-42

Sudarmiatin. 2019. “The Effect of Destination Image on Destination Branding and Revisit Intention”, Proceedings of the 2019 International Conference on Organizational Innovation - Advances in Economics, Business and Management Research, Atlantis Press. Vol. 100

Sugiyono, 2013. "Statistika untuk Penelitian", Cetakan ke - 23, Bandung: Penerbit Alfabeta.

Sugiyono, 2017. "Metode Penelitian Kualitatif: Untuk penelitian yang bersifat: eksploratif, enterpretif, interaktif, dan konstruktif". Bandung: Penerbit Alfabeta.

Sugiyono, 2018. "Metode Penelitian Bisnis", Edisi ke-3, Bandung: Penerbit Alfabeta.

Sukaatmadja, I Putu Gde dan Yasa, N.N.K., 2020, "Manajemen Pemasaran Pariwisata", Penerbit Lakeisha.

Sukawati, Tjokorda Gde Raka, 2014, "Merajut Nilai Nilai Kearifan Lokal Untuk membangun keunggulan daya saing berkelanjutan (Studi Etnografi pemasaran Pariwisata di Ubud)", Program Doktor Ilmu Manajemen Pasca Sarjana, Fakultas Ekonomi dan Bisnis, Universitas Brawijaya Malang.

Sukawati, Tjokorda Oka A.A, 2006, “Kembang Rampai Desa Ubud”, Pustaka Nayottama.

Timur, Beybala. 2018. "Service quality, destination image and revisit intention relationship at thermal tourism business". Journal of Gastronomy, Hospitality and Travel (JOGHAT). Vol. 1, No. 1, pp. 38 - 48

Tosun, Cevat. Dedeoglu, Bekir Bora and Fyall, Alan. 2015, "Destination service quality, affective image and revisit intention: The moderating role of past experience" Journal of Destination Marketing and Management. Vol. 4, No. 4, pp. 222-234

Trip Advisors, 2020. www.tripadvisor.com/TravelersChoice-Destinations

Trip Advisors, 2017. www.tripadvisor.mediaroom.com/2017-03-21-TripAdvisor-Announces-Top-DestinationsAround-the-Globe-in-2017-Travelers-Choice-Awards

Vermeulen, Ivan E. and Seegers, Daphne. 2008. "Tried and tested: the impact of online hotel reviews on consumer consideration", Tourism Management, Vol.30, No. 1, pp. 123-127.

Webster, F.E.Jr and Keller, K.L, 2004. "A roadmap for branding in industrial markets", Brand Management, vol.11, No. 5, pp. 388-402.

Wiratama, IG, Rahyuda, K and Yasa, N.N.K., 2017, Pengaruh Citra Toko Dan Kualitas Pelayanan Terhadap Kepercayaan Pelanggan Serta Niat Beli Produk Private Label Alfamart, Buletin Studi Ekonomi, pp. 239-249

WTO, 2020, http://www.unwto.org

Yeoh, E., Othman, K., and Ahmad, H. 2015. "Understanding medical tourists: Word-of mouth and viral marketing as potent marketing tools". Tourism Management, Vol. 34, pp. 196-201.

Yulianti, N, Suprapti, N.W.S, Yasa, N.N.K. 2014. "Pengaruh Citra Toko Terhadap Kepuasan Pelanggan dan Niat Beli Ulang Pada Circle K Di Kota Denpasar”, Jurnal Manajemen Strategi Bisnis Dan Kewirausahaan, Vol. 8, No. 1, pp. 36-44

Yustiani, Dwi. 2019. “Tingkat penghunian kamar akomodasi Provinsi Bali 2019”. BPS Provinsi Bali

Zhang, Yi. 2015. The Impact of Brand Image on Consumer Behavior: A Literature Review. Open Journal of Business and Management, Vol.3, pp. 58-62

Zeithaml, Valerie A, 1988. "Consumer perceptions of price, quality and value; a means end model and synthesis of evidence", Journal of Marketing, Vol. 52, pp.35 - 48. 